47歳，男性，食道静脈瘤出血に対して胃全摘術が施行されている。その術後10年目の 昭和58年食道空腸物合部から食道にかけての静脈瘤出血を来した，5\%エタノールアミ ンオレイトによる硬化療法を繰り返する出血をくりかえすため, 輸入脚の離断とつり上 げ空腸の静脈の結禁街を行い一時的な止血を得た。さららに再出血を来したためつり上げ 空腸の静脈枝と堅静脈とのシャント術を施行。術後硬化療法を追加した。平成元年 4 月 筋娄樎性側索硬化症に上る呼吸不全にて死亡したが剖検にてシャントの開存が確認され た. 释過中脱症は認められなかった。食道静脈痹症例に対する胃全摘術は出来るたけ避 けるべき術式と考えるが，胃全摘術後の静脈瘤再発に対してはこの新しい選択的シャン ト街が有奻であると考えられた。

索引用語：胃全摘術後静脈瘤，腸間膜搫脈枝腎静脈シャント術

はじめに

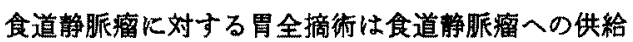
血行路を絶つことにより食道静脈瘤の根治治療のひと つになると考えられがちである。しかし，胃全摘後の 再建荿器としては門脈系の空腸が用いられる場合が多 く，食道空腸物合部から食道にかけての静脈落の再発 か問題となる。胃全摘術後10年目に食道空腸吻合部か ら食道にかけての静脈癉出血を来した症例を経験し だ。そ治療に難涉し最終的につり上げ小腸の静眽 枝を門脈と分離し㷅静眽と吻合した。術後 4 年 7 カ月 筋萎緶性側索硬化症 (ALS) にて死亡するまで軤眽㾇 の制御が容易であった。このような胃全摘後静脈瘤に 対する治療法としてこのンャント術は有用で，また新 しい選択的シャント手術と考えられたので報告する。

$$
\text { 症例 }
$$

患者：46歳，男性

家族歷：特記すべき事なし

既往歴：昭和47年 3 月 (36藏)Banti 症候群による食 道静脈留出血との衍中猃断にて胃全摘, 摘脾術をらけ た. 再建術式は Billroth-II 法に準した食道空晹端側吻 合衍で，Braun吻合衍が併設されていた。

1991年 5 月31日受付 1992年 1 月18日採用
現病歴：昭和58年 2 月（46歳）吐下血あり, 近医に て保存的治療を受け止血. 昭和58年 3 月24日再度昍下 血あり当科紹介となる。緊急内視鏡検查にて F $2 \mathrm{CbRC}$ (十)の食道静脈癌が認められはかに出血点がないこと から，食道静脈雷出血の緊急例として $5 \%$ ×タノール アミンオレイトを用いた硬化㞠法が施行されだ。その 後計 3 回の硬化療法を施行し静脈瘤恃軽快したが, 同 年 5 月 5 日食道空晹吻合部付近加 5 出血. 空晹粘膜の 点状出血もあり, 硬化寮法の限界と考え全身状態の改 善をはかり，待期的手術に踏み切った。このときの検 查成績を表 1 亿示す。

<第一回手術>同年 6 月 29 日開腹下に消化液の逆流 防止のための輸入脚の離断とつり上げ空腸の静脈枝と 門脈との離断をむこなった。術中所見ては肝は注注正 常で旰硬变や門眽閉塞は認められなかった。

術後内視鏡所見では食道静脈瘤はF1CWRC $(-)_{i}$, なり，空腸の発赤も軽快した。しかし，昭和59年 4月 下血出現.このときは保存的治療で軽快したが; 同年 9 月にる再度吐下血をみた。内視鏡検查で F2CwRC (一)と形驡面での增䔡が認められたが出血点性不朋で あった。 その後も硬化療法を施行したが少量の昍下血 を綝り返し，かつ門脈とつり上げ脜管の静脈との交通 が認められたため同年10月10日シャント手術を施行し 
た.

く第二回手術〉つク上げ腸管の小腸静脈は約 $6 \mathrm{~mm}$ に拡張しており門脈とは直接交通は認められなかった が術中造影にて食道静脈瘤に向から血行か確認された （図1）。この静脈を左精索静脈起始部を切除した左腎 静脈之端側吻合した(図 2)．この際門脈系とできるだ け分離を行った。

第二回目の手術後の内視鏡所見は FICwRC $(-)$ と 軽块したが消失にはいたらなかったため，同年12月， 昭和60年 8 月，11月，12月に硬化療法を追加した。食 道静脈瘤の消失が得られた。

\section{表 1 血湤生化学的検查成模}

\begin{tabular}{lr|ll} 
RBC & $363 \times 10^{4} / \mathrm{mm}^{3}$ & TP & $6.4 \mathrm{~g} / \mathrm{dl}$ \\
WBC & $5800 / \mathrm{mm}^{3}$ & & \\
$\mathrm{Hb}$ & $10.9 \mathrm{~g} / \mathrm{dl}$ & $\mathrm{A} / \mathrm{G}$ & 2.03 \\
Plt & $26.2 \times 10^{4} / \mathrm{mm}^{3}$ & & \\
& & $\mathrm{Na}$ & $140 \mathrm{mEq} / \mathrm{l}$ \\
GOT & $75 \mathrm{IU} / \mathrm{l}$ & $\mathrm{K}$ & $4.7 \mathrm{mEq} / 1$ \\
GPT & $62 \mathrm{IU} / 1$ & $\mathrm{Cl}$ & $107 \mathrm{mEq} / 1$ \\
ALP & $19.7 \mathrm{KA}$ & $\mathrm{Ca}$ & $9.2 \mathrm{mg} / \mathrm{dl}$ \\
LDH & $512 \mathrm{IU} / \mathrm{l}$ & & \\
& & TC & $148 \mathrm{mg} / \mathrm{dl}$ \\
TB & $0.9 \mathrm{mg} / \mathrm{dl}$ & $\mathrm{ChE}$ & $0.51 \Delta \mathrm{ph}$ \\
& & ZTT & $8.5 \mathrm{U} / 1$ \\
TTO & $50 \%$ & TTT & $6.3 \mathrm{U} / 1$ \\
HPT & $60 \%$ & & \\
ICGR & $31.8 \%$ & &
\end{tabular}
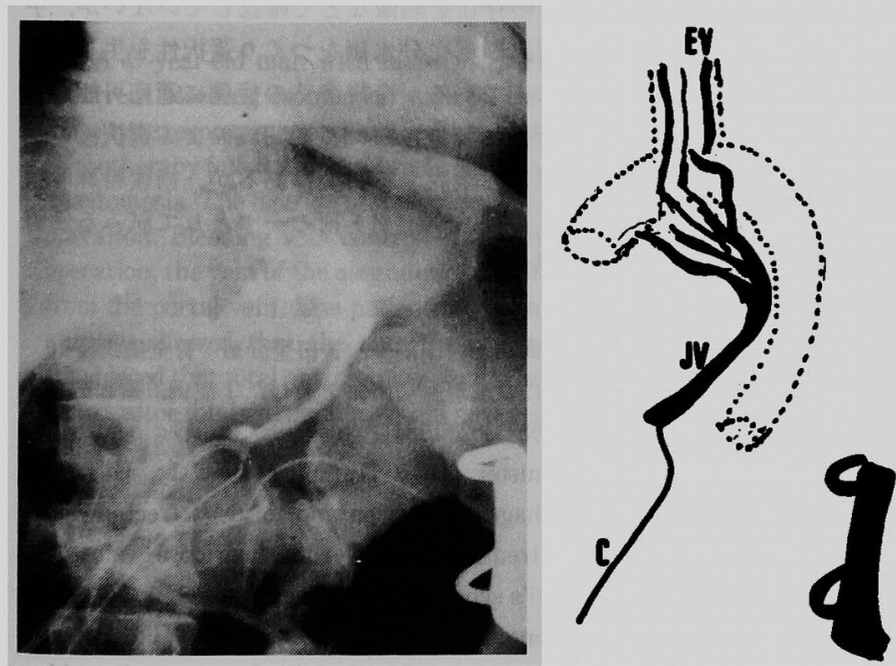

図 1 術中つク上げられた空腸静脈（JV）からの造影：門脈本幹との交 通は認められず食道周囲に向から静脈 (EV) が造影される。
予後：炤和 62 年 8 月頃から筋萎縮が上肢を中心に認 められるようになり昭和63年 1 月筋萎縮性側索硬化症 の診断をうける，平成元年 4 月 18 日呼吸不全にて死亡 した。シャント術後脳症は認められなかった。 また， ALS 診断後には食道の内視鏡検查は施行されなかっ たが静脈瘤出血は認められなかった。

剖検所見：肝臟は $835 \mathrm{~g}$ で肝硬変は認められなかっ た。グリンン䩗に軽度の細胞漫潤が認められるのみで 特発性門脈压六進症之考えられた。その時シャントの 開存が確認された（図3）。

\section{考案}

食道静脈瘤に対する胃全摘術は1947年 Phemister らによって Banti 症候群の 2 例に施行された 初でこれは静脈瘤出血に胃酸の関与が重要であると して1949年 Baronefsky らによって報告された食道 静脈瘤に対する広範囲胃切除に加え静脈瘤出血の部位 除去をる目的として施行されている.これら胃全摘さ れた 2 例の予後をみると 1 例は術後 3 カ月余で経過順 調とのことであるが， 2 年 8 力月経過した他の 1 例で は経過中に静脈瘤からとの記載はないが 2 度の出血が みられている，その後 King ら4) Habif ${ }^{5)}$ は静脈瘤に

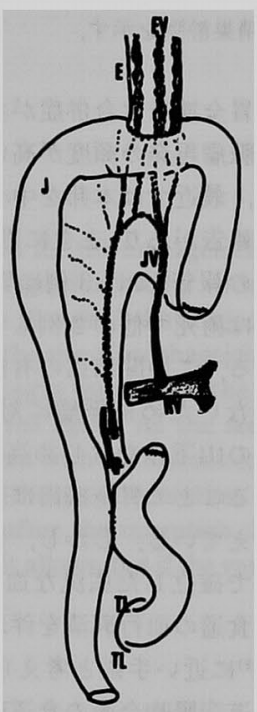

図2 手術のシェーマ:つり上げら れた空腸 $(\mathrm{J})$ は輸入脚で離断され、 空腸静脈 (JV) は一方端は左腎静 脈 (RV) と端側吻合され門脈側は 離断された，Eは食道，TLは Treitz 勒带を示す。 

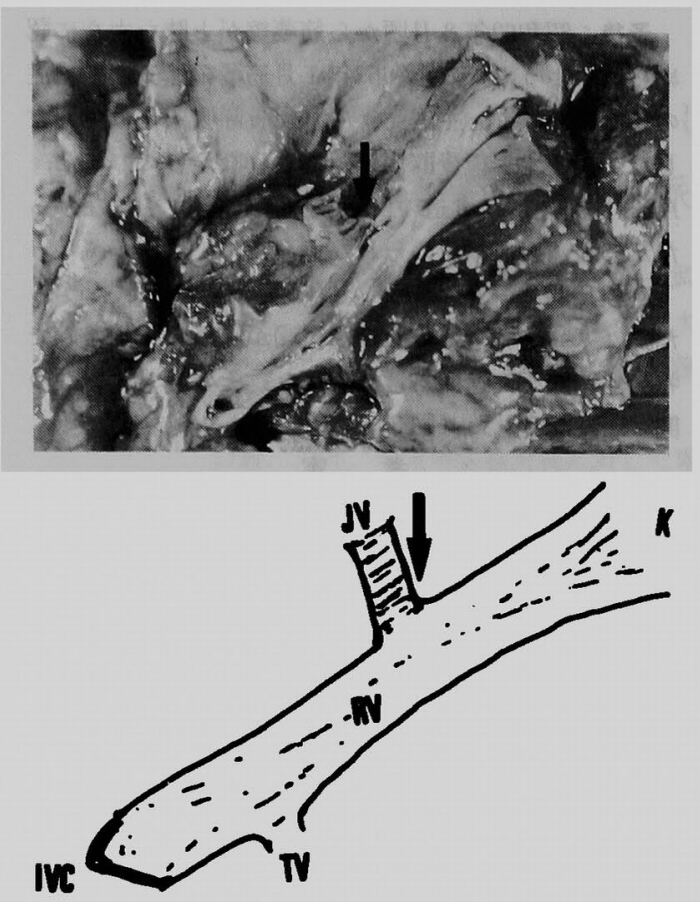

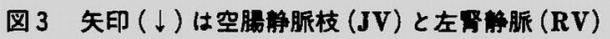
との吻合部：Kは監葴側，IVCは下大㬹脈側，TV は精巣静脈を示す。

対する胃全摘術は合併症が多いこと，長期成績では出 血や静脈瘤再発の頻度が高いことを報告している。

一方，最近では本邦を中心に食道静脈瘤を伴ら胃癌 症例の報告があり，ときに胃全摘術が施行されている. 山下らの報告)では 3 例に胃全摘がなされており，ち ち 1 例は術死で他の 2 例す 6 カ月と 1 年 5 カ月で死亡 している.この間出血の有無や静脈瘤再発については 記載がないため静脈瘤に対する効果は判定できない が,この山下らをはじめ高橋ら”は食道への血流が遮 断されることで胃全摘術は直達手術と同様の効果があ ると考えている。しかし，胃全摘による消化管の離断 は本邦で確立した広汎な血行郭清を伴ら直達手術 ${ }^{8)}$ 異なり食道の血行郭清を伴わないはぼ Walkerの食道 離断術”に近い手術と考えられ早期の再発が予想され る. 食道空腸吻合術の食道静脈瘤症例の報告は本症例 についての著者らの発表抄録"を引用した米川の報 告 ${ }^{10)}$ や大谷 ${ }^{111}$, 工藤 ${ }^{121}$, 福田 ${ }^{13)}$ の報告があるように散発 的ではあるが報告を見るよらになった。このような食 道静脈瘤再発のメカニズムはまた十分明かではない が, 再発を防止する目的で再建臓器として門脈本幹に
近い空腸でなく大腸を用いるという考えもある。しか しいずれにせよ，胃病変のない症例ではもちろん胃病 変があっても門脈压穴進症を有する症例に対する胃全 摘はできるだけ避けるへささであると思われる。

では食道空腸吻合術後の静脈瘤出血の治療はいかに すべきであろらか. 現在硬化療法の治療成䋶が向上し とくに術後再発症例での効果が評価されている，本症 例です硬化療法を試み食道静脈瘤には一定の効果が認 められたが吐下血を長期に防止することはできなかっ た ${ }^{14)}$. 本症例の出血部位は最初は食道静脈瘤からで あったが，次第に食道空腸吻合部付近となり空腸にも 発赤が出現しており硬化療法のみでの止血には限界が あるものと思われた，そこで私達は門脈領域との遮断 を試みさらにシャント手術を加えたものである。

さて，門脈圧方進症におけるシャント術の問題点は その開存性と選択性である。著者らの行ったシャント 術は術後 4 年余剖検にてその開存が確認された. また, 術後血管撮影はされていないが経過中脳症は認められ なかった．結局 2 度の手術でつり上げた空腸の静脈は 門脈と切離され腎静脈と吻合されたことで結果的にこ の空腸の静脈系は門脈系から分離され一種の選択的 シャント術となったすのと考えられた，さらにこの術 後期間中脳症もなく選択性す保たれていたものと思わ れる.これは1984年 Warren らが報告した脾摘後や脾 静脈血栓時の静脈瘤に対する選択的減圧術 ${ }^{15)}$ に近いも のである，また，本症例では私達の提唱している門脈 域分水嶺 ${ }^{16)}$ の存在を画像などで確認していないが，手 術的に血行遮断部に分水嶺をつくり選択珄を生しさせ たものと考えている. 今後多くの症例に適応可能か否 かを，血管径や流量さらに長期間におよぶ選択性の確 保などの点から検討する必要はあるが, 術後特殊静脈 瘤に対する選択的シャント術の一つとして試みる価值 があると思われる。

\section{文献}

1）清水武昭，村山裕一，吉田奎介他：胃全摘術後 10 年目に食道静脈瘤出血を来した 1 症例，新潟医会 誌 $98: 302,1984$

2) Phemister DB, Humphreys EM: Gastro= esophageal resection and total gastrectomy in the treatment of bleeding varicose veins in Banti's syndrome. Ann Surg 126 : 397-410, 1947

3) Baronofsky IP, Wangensteen $\mathrm{OH}$ : Portal hypertension with special reference to the acidbase factor in the causation of hemorrhage and 
extensive gastric resection in its treatment. Surgery $25: 135-138,1949$

4) King $H$, Shumacker HB: Venous shunt procedures for portal hypertension in children. Surgery $43: 680-682,1958$

5) Habif DV: Treatment of esophageal varices by partial esophagectstrectomy and interposed jejunal segment. Surgery $46: 212-237,1959$

6）山下忠義, 芦田 宽, 石川羊男他：所硬変を合併し た胃癌の手術，消外 3:443-450, 1980

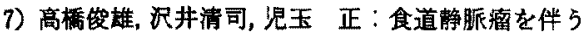
早期胃癌の治療, 消外 $9: 1395-1399,1986$

8）柇浦光雄，市原花六，野村 满他：門脈王穴進症の 外科治療，とくに東大第 2 外科法について，日医新 報 $2410: 7-11,1970$

9) Walker RM : Tramsection operations for portal trypurteufion. Thorax 15:218-224, 1960

10) 米川甫, 島 伸吾, 杉浦芳章他：Roux-Y 物合の

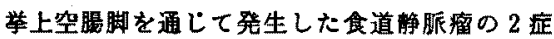
例，日消外会誌 $20: 1948-1951 ， 1987$
11）大谷吉㫜，城田 実, 武井秀夫他：胃全摘術後に発 生した興朱ある食道静脈留の 1 例，日消病会誌 $74: 100,1977$

12）工藤十右衛門，岡部粑正，河井啓三他：胃全摘後に 発症した食道軤脈瘤の1例，日消病会誌 $83: 153 ，$ 1986

13）福田正春,芦田 宽, 寺方㴽一他：噴閏側胃切除・

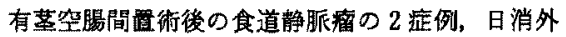
会誌 $23: 1867-1871,1990$

14）塚田一博, 吉田奎介, 武藤腪一：街後再出血例の治 㙩方針, 消外 7:563-569, 1984

15) Warren WD, Millikan WJ Jr, Henderson JM, et al: Selective variceal decompression after splenectomy or splenic vein thrombosis. Ann Surg $199: 694-702,1984$

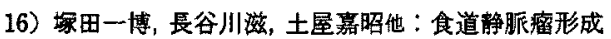
における局所循環六進状態一罥全摘, 道空腸吻

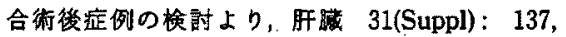
1990

\title{
A NEW SHUNT PROCEDURE IN A PATIENT WITH RECURRENT ESOPHAGEAL VARICES 10 YEARS AFTER ESOPHAGOJEJUNOSTOMY -A CASE REPORT-
}

\author{
Kazuhiro TSUKADA, Takeaki SIMIZU*, Keisuke YOSHIDA, \\ Shigeru HASEGAWA and Terukazu MUTO \\ First Department of Surgery, Niigata University School of Medicine \\ -Department of Surgery, Shinrakuen Hospital
}

A 47-year-old man with idopathic portal hypertension was admitted to our hospital for the management of recurrent bleeding esophageal varices. He had undergone total gastrectomy and esophagojejunostomy with the loope type reconstruction like the Billroth II because of bleeding esophago-gastric varices 10 years before. Injection sclerotherapy failed to control recurrent bleeding of the varices. Bleeding continued from the site of esophagojejunal anastomosis. The ligation of the vein of a jejunal segment which is ascending to the esophagus was done at the first operation. Bleeding was controlled for only ten months. But variceal bleeding occurred again. As the second operation, the vein of the ascending jejunal segment was anastomosed to the left renal vein with the disconnection from the portal vein. The patient died of amyotrophic lateral sclerosis 55 months after the shunt operation. The autopsy showed that the shunt was patent. Encephalopathy was not encountered after the operation. It is considered that total gastrectomy should be avoided for esophageal varices as possible as it allows, but if the varices recurs after total gastrectomy, this new selective shunt procedure may be recommended. 